\title{
EFFECT OF PRE AND POST CALVING BODY CONDITION SCORE ON BODY CONDITION SCORE CHANGE, BLOOD METABOLITES AND OXIDATIVE STRESS IN FRIESIAN DAIRY COWS IN EGYPT
}

\author{
Mohamed El-Sharawy ${ }^{1}$, Ibrahim Mashaly ${ }^{2}$, Mostafa Kotb ${ }^{2}$ and Ibrahim El-Shamaa ${ }^{1}$ \\ 1-Animal Production Department, Faculty of Agriculture, Kafrelsheikh University, 33516, Egypt, 2- Animal \\ Production Research Institute, Agriculture Research Center, El-Dokki, Giza, Egypt
}

Body condition score (BCS) provides a reliable and easy method to evaluate the nutritional status, efficacy of feeding system, changes in energy reserves and the relation between milk production and feed intake. Therefore, the aim of study was to determine the effect of pre and post calving body condition score (BCS) on BCS change, blood metabolites and oxidative stress in Friesian cows. At 60 days before expected calving (90 Friesian cows) were grouped according to their BCS to three experimental groups, group 1: less than 3 (30 cows), group 2: from 3-3.5 (30 cows), and group 3: more than 3.5 (30 cows). Blood samples were taken at day 60, 0, 7, 14 and 60 days' post-partum. Serum were harvested and stored frozen at $-20{ }^{\circ} \mathrm{C}$ until assayed for nonesterified fatty acids (NEFA), $\beta$-Hydroxybutyrate (BHBA) and Haptoglobin (HP). Also, serum concentrations of albumin (AL), triglycerides (TG), glucose, cholesterol (CL), aspartate amino transferase (AST), alkaline phosphatase (AP) were analyzed. Results from this study showed that the body condition score is relatively correlated with body weight and back fat thickness. The cows having high BCS at calving had lost more condition and body weight compared with cows have low body condition and lesser body weights.

Keywords: Calving body condition score, blood metabolites, oxidative stress, Friesian dairy cows 